\title{
Chromosome 6
}

National Cancer Institute

\section{Source}

National Cancer Institute. Chromosome 6. NCI Thesaurus. Code C13222.

The designation for each member of the sixth largest human autosomal chromosome pair. Chromosome 6 spans more than 170 million base pairs and represents between 5.5 and $6 \%$ of the total DNA in normal diploid cells. 